\title{
Sanatta Mekân Kurgusu Bağlamında Joseph Beuys Yapitları*
}

\author{
Aylin BEYOĞLU*
}

BEYOGLU, A. (2019). Sanatta mekan kurgusu bağlamında Joseph Beuys yapıtları. YEDİ: Sanat, Tasarım ve Bilim Dergisi, Kış 2019 (21), s. 33-41.

Araştırma Makale / Research Article

Özet

1921 yılında Almanya'nın Krefeld şehrinde doğan Joseph Beuys; önce Tıp okumaya karar vermiş daha sonra okulu bırakarak; Alman Hava Kuvvetleri’ne katılmıştır. Kırım'da pilot olarak görevliyken uçağı düşürülmüş, sanatçıyı kurtarmak için vücudunu yağ ve keçe ile sarmışlardır. Bu olay sanatçının yaşamını, yapıtlarını ve düşüncelerini etkilemiştir. Fluxus sanatçıları arasında yer alan Beuys yapıtlarında renkle, nesnelerle ya da biçimlerle psikolojik ve sembolik etkiler yaratmak istemiş, bu etkilerle çeşitli mesajlar vermeye çalışmıştır. Sanatçı farklı düzeneklerle oluşturduğu yapıtlarını gerçek mekânlar içerisinde kurgulamıştır. Sanatçı sanatıyla bir eylemci, bir kuramcı, bir oyuncu ve bir şaman olduğunu ortaya koymuştur. Joseph Beuys’un yapıtlarını mekân kurgusuna ilişkin bir örnek olarak incelemek ve mekân kurgusu bağlamında önemini göstermek makalenin temel amacını oluşturmaktadır. Betimsel tarama modeli ile gerçekleştirilen araştırmada, sanatçı Beuys'un sanatı ve yapıtları ile ilgili literatür taraması yapılmıştır. Beuys'un yapıtlarının incelenebilmesi için öncelikle sanatçının yaşamı ve sanatı hakkında kısaca bilgi verilmiş; yapıtları arasından konuya uygun olan örnekler seçilerek incelenmiştir. Bu araştırma Beuys’un yapıtları ile sınırlandırılmıştır. Araştırmanın sonucunda; sanatçının mekân kurgusu bağlamında yapıtları değerlendirilmiştir. Sanatçının mekânlarını kurgulayarak yapıta mekânı dâhil etmesiyle, yapıtlarını oluşturmak için kullandığı malzemeler ve düzenlemeler sanatın yeniden tanımlanmasına katkı sağlamıştır. Sanatçı, yapıtlarında oluşturduğu düzeneklerin mekân içerisinde bir bütün olarak algılanmasını sağlamaya çalışmıştır.

Anahtar so̊zcükler: Fluxus, Sanat, Sanatçı, Sandalye, Yapit.

\section{Works Of Joseph Beuys Within The Context Of Locale In Art}

\section{Abstract}

Born in 1921 in Krefeld, Germany; Joseph Beuys initially decided to study medicine, then quit school to join the German Air Force. While serving as a pilot in Crimea, his plane was shot down and the artist's body was wrapped in oil and felt to save his life. This incident impacted the artist's life, his works and his thoughts. One of the Fluxus artists, Beuys sought to create psychological and symbolic effects in his works using colors, objects or shapes, giving various messages with such effects. The artist designed his works created with various contrivances in real locations. In his art, the artist demonstrated his identity as a protestor, a theorist, an actor and a shaman. The fundamental purpose of this study is to examine the works of Joseph Beuys as an example of the relation of works to the design of locale. Carried out using descriptive survey model, the study examined the literature on the works of the artist Beuys. To examine Beuys' works, brief information on the artist's life and art is initially provided. Then the works of the artist that are in line with the subject have been selected and examined. This study is limited to the works of Beuys. The study contributes to the re-definition of the art by identifying the locales designed and included in the works by the artist as well as materials and arrangements used to create the works. The artist aimed to ensure that the contrivances in the works are perceived integrally with the locale.

Keywords: Fluxus, art, artist, chair, work. 


\section{Giriş}

Joseph Beuys (1921-1986); çok yönlü bir sanatçı olmasının yanı sıra; politikacı ve akademisyen tanınmaktadır. Beuys yapıtlarını; farklı yaklaşım biçimleriyle de doğadan elde edilen malzemelerle birlikte kurguladığı mekânlar içerisinde oluşturmaktadır. Sanatçının yapıtlarında malzemeler oldukça önem taşımaktadır. Sanatçı bir çalışmasında, şekli belli olmayan amorf malzemelerle; geometrik, ölçülü biçili nesneler arasındaki karşıtlığı; sert ve yumuşak malzeme bütünleşmesini kavramsal düzeyde sorgulamıştır (Genç, 2007, s. 169). Sanatçı yapıtlarında kullandığı malzemeleri sembol olarak kullanmış çeşitli mesajlar vermeyi amaçlamıştır. Bu malzemelerden en temel olanları yağ, keçe ve bakırdır. Sanatçı bu malzemelerin biçimlendirilmemiş, kaotik bir durumda bulunmasından yola çıkmıştır. Kullandığı yağın ısı etkisiyle biçiminin değişmesi, keçenin hayvan kılının sıkıştırma yoluyla oluşması gibi ısı ya da başka bir katalizörle bu belirsiz durumların biçimli, billursu bir duruma taşınabilmesi sanatçının malzemeleri kullanmasında etkili olmuştur (Paust, 2005, s. 17). Sanatçı ayrıca; ısı veya enerjinin sembolü olarak balı, düşünce paylaşma aracı olarak ele aldığı kara tahtayı, odaklanmanın ve yön bulmanın sembolü olarak el fenerini ve kanı, bitki özsuyunu, bitkileri, kemikleri, canlı cansız hayvanları, toprak ve kaya parçaları gibi birçok farklı organik ve inorganik malzemeyi kullanmıştır (Merdaner, 2010, s. 57).

Sanatçı yapıtlarını kullandığı malzemelerle galeri ya da gerçek mekânlar içinde oluşturmuştur. Sanatçının yapıtları mekâna uygun şekilde mekânla birlikte kurgulanmış, mekâna özgü yapıtlar olarak görülmektedir. Sanatçı bazı yapıtlarında mekânın tamamını kurgulamış ve mekânı bağlamından uzaklaştırarak yapıtıyla birlikte oluşturmuştur. Sanatçının sanata yeni bir açılım getirmeyi amaçlayan yaklaşımı, bütünlüğü ve tutarlılığı olan arayışlardan biri olduğu için önemli bir örnek oluşturmaktadır. Beuys'un sanat anlayışı, çağdaş sanatın dayanakları olan modernizm ve avangard kavramlarının incelenmesine olanak tanıyacak bir noktada bulunması sanatın bir düşünme biçimi olarak yeniden kurgulanması sürecinin bir parçası olmuştur (Şen, 2006, s. 1).

\section{Yöntem}

Araştırmada; Beuys'un sanatı ve yapıtları ile ilgili literatür taraması yapılmıştır. Özellikle mekân kurgusu bağlamında sanatsal üretimde bulunan Beuys'un yapitları üzerinde araştırmalar yapılmıştır. Araştırma nitel araştırma tekniğiyle yürütülerek betimsel tarama modeli ile desenlenmiştir. Bu araştırmanın verileri, araştırmanın modeli gereği basılı kaynakların; konuyla ilgili ulusal ve uluslararası yazınsal ve görsel kaynaklar, ilgili yapıtların incelenmesine dayandırılarak toplanmıştır. Araştırma, Sanatta Mekân Kurgusu konusu ve Beuys'un yapıtları ile sınırlandırılmıştır. Sanatçının yapıtları, mekân kurgusu bağlamında konuya uygun örnekler içermesi bakımından seçilmiştir. Beuys ve, yapıtlarının incelenebilmesi için öncelikle, sanatta mekân kurgusu, Beuys ve sanatı hakkında kısaca bilgi verilmiş, daha sonra yapıtları ele alınarak incelenmiştir.

\section{Sanatta Mekân Kurgusu}

Sanat eseri, üzerinde zaman harcayıp kültürel yorumlar ve fikirlerin biraraya gelmesiyle oluşmaktadır. Sanat eseri, değişen toplum kültürlerinin sanat eserinde yer bulan ifadeci ve yorumcu düşünce anlayışının ortaya çıkmasını sağladığı gibi mekânın kavramsal yapısını da oluşturmaktadır. Sanat imgeleri ve tasarımları mekânla ilişki kurarak kendilerini mekânda var etmektedirler. Her eserin yapısallığı ile değişken bir mekânı bulunmaktadır. Bunlar birbirini tamamlayan ve var eden iki olgudur. Sanatın ifadeci tavrını birlikte oluşturan iki kavramdır.

Sanatın kuramsal yapısını değiştiren ve var eden kültürel yapı aynı zamanda algısal boyutunu da var ettiği estetik kurgusuyla tanımlamaya çalışmaktadır. Sanat nesnesi bu kimliğiyle artık hacim, yüzey, ışık-gölge ve renk gibi öğelerin dışında farklı ifadelerle kendini yaşatmaktadır. Minimalist düşünce artık salt kütleyi değil, ifadeci tavrıyla boşluğa yeni yorumlar katan bir tavır sergilemektedir.

Geçtiğimiz yüzyıllarda etkin olan mekân anlayışları sosyal, kültürel ve ekonomik yapılarıyla değişimlere uğramıştır. Gerek bilimde, gerekse sanatın ortaya koyduğu değerlerle yeni boyutlar kazanmıştır. Toplumsal etkileşimler ve süreklilikteki kalıcılık etkileri mekânı bugüne taşırken kültürel oluşumunu da korumuştur.

İmgelerin yapısı itibariyle gerek üç boyutu, gerekse soyut anlam veren yorumları ile mekân anlayışı özünde nesneyle kurulan ilişkiyle var edilmektedir. Nesneler bulunduğu yer itibariyle mekânı sahiplenirken, mekânda “uzam” anlamı 
içerisinde nesneyle kendini ilişkilendirmektedir. Bu yapıda mekân yapıta, yapıt mekâna bir anlam yüklemiş olmaktadır. Mekânsal kurguda yapıt algılanırken biçimler ve boşluk birbirini tamamlayarak bir oluşum sergilemektedirler. Üç boyutlu sanat eserlerinde anlamları değişerek farklı boyutlar sergileyen nesneler, içinde bulunduğumuz dönemde farklı bir yapısal kimlik oluşturarak ifadede farklı unsurlar yansıtmaktadırlar. Dışarıdan izlenen bakılabilen yapısı değişmiş, alışılmışın dışında bizi farklı bir algıyla bağ kurmaya teşvik etmeye başlamıştır. 1960’lı yıllar Kavramsal Sanatla birlikte, hem yeni düşünce oluşumuyla hem de sanatçıların üretim şekliyle, kendini biçim ve malzemede göstererek fikir veya kavramın sanat eserinin en önemli parçası olduğunu anlatmıştır. Düşünceyi öne çıkaran bu alan her türlü nesnenin sanatın bir malzemesi olabileceğini göstermiştir. Güzel olan ya da estetik değere sahip olabilecek herşey toplumsal kültür yapısı içinde kendisini var edip anlatma imkânı bulabilmektedir.

Mekân; iç mekân, dış mekân ve kentsel mekân gibi çeşitlendirilerek kültürel yapıları içinde imgesel farklılıklara sahip olmaktadır. İmgelerin düzen içerisinde kendilerini ifade şekilleri kültürel farklılıkların da varlığını belirlemiş olmaktadır.

Amerika ve Avrupa'da 1960'larda başlayan sanatta serbest mekân kullanımı ya da mekânın sanat nesnesi olarak kullanımı, sanat yapıtlarının dış görünüşlerinin de değişmesine neden olmuştur. Bu yıllarda Amerika'da ve bazı Avrupa ülkelerinde ortaya çıkan ortak biçimsizlik durumu, farklı disiplinlerden ve anlayışlardan üretim şekillerinin sanat yapıtlarında birlikte veya grift bir şekilde ortaya konmasıyla başlamıştır. Bu eserlerle birlikte görsel sanatlar sözüyle anlaşılan görsel yapı, sadece resim ve heykel olmaktan çıkmış, heykelin mekânla birleştiği, resmin yüzeyinden koparılıp mekânla algılanır olduğu farklı anlayışların birleştiği bir süreç haline gelmiştir (Coşkun Onan, 2017, s. 38).

\section{Joseph Beuys ve Sanatı}

1921 yılında Kuzeybatı Almanya'da bulunan Krefeld şehrinde doğan Beuys, daha çok Kleve ve Rindern'de büyümüş ve orta sınıf bir ailenin tek çocuğu olarak yetişmiştir. Önce Tıp okumaya karar veren sanatçı daha sonra okulu bırakarak, 1940 yılında gönüllü olarak Alman Hava Kuvvetleri'ne katılmış, II. Dünya Savaşı`nda Alman Hava Kuvvetleri’nde çarpışmıştır. 1943’te Kırım'da savaş pilotu olarak görevliyken uçağı düşürülmüş, yaşamını uçağın düştüğü yerde onu kurtarmaya gelenler kurtarmıştır. Soğuktan donmasını önlemek amacıyla sanatçının vücudu yağ ve keçe ile sarılmıştır (Antmen, 2000, s. 17). Bu olay sanatçının yaşamı, yapıtları ve düşünce dünyasında değişikliklere sebep olmuştur. Ölüm ve yaşam arasındaki o ince çizgide, savaşın ve yayılmacı politikaların içyüzünü kökten kavrayan sanatçı, düşünsel bir eylemci olarak kendi kültürünü sağaltma girişimlerinde bulunacaktır. Yaşamı, çevreyi, politik olayları yorumlayarak kendi özündeki tinsel ve düşünsel değerleri ülküleştiren bu arayışla, insani bir yabancılaşmaya kafa tutmak istemiştir (Şahiner, 2013, s. 60).

Sanatçı, 1945 yılında bir İngiliz esir kampında kalmıştır. 1946-51 yılları arasında Düsseldorf Sanat Akademisi'nde heykel okumuş, 1961 yılında ilk kişisel sergisini açmıştır. Daha sonra profesör unvanıyla Düsseldorf Sanat Akademisi'ne dönmüştür (Sanat Atlası, 2010, s. 558). Sanatçı; enstalasyon çalışmaları, happening'leri ve desen çalışmaları ile hem önde gelen bir siyasi sanatçı hem de eğitim sistemlerine karşı olan tavrıla bilinen bir hoca olmuştur. Akademi'nin reddettiği öğrencileri kabul ettiği için okuldan kovulmuş, bu yüzden Uluslararası Yaratıcılık ve Disiplinlerarası Araştırma Özgür Üniversitesi’ni kurmuştur. Rudolf Steiner'in öğretilerinden esinlenen sanatçı, doğa ve ruhun yeniden birleşmesinin ve nesnelerin ifadeci figüratifliği aracılığıyla yaşamın karmaşasının görsellikle ifade edilmesinin peşine düşmüştür. Alışılmışın dışında malzeme ve teknikler kullanarak tüm disipliner sınırlara uzanarak görsel bir dağarcık üretmiştir (Buchholz Buchholz, Bühler, Hille, Kaeppele, Stotland, 2012, s. 498). "Pek çok sanatçı gibi Beuys da, herhangi bir sanat türünde çalışmanın bile gerici bir hareket, eşitlikten yana olmayan toplumları destekleyen bir etkinlik olduğunu anlamıştı." (Lynton, 2004, s. 336). Sanatçı, sanatçının rolü ile nesnelerden enerji alan ve nesnelere yeni güçler, yeni anlamlar yükleyen bir şamanın rolü arasında paralellik görmüştür (Beykan, 1997 ed., s. 43).

Sanatçı, 1962 yılında Fluxus hareketine katılmıştır. 196070 yılları arasında öne çıkan Fluxus sanatçı kolektifi; toplumsal ve siyasal eylemlilikle bir arada sanatsal deneyler yapmanın hararetli savunuculuğunu üstlenen bir uluslararası avangard grup olmakla birlikte saflarında Joseph Beuys, John Cage, Charlotte Moorman, Yoko Ono ve Nam June Paik gibi isimler yer almıştır. Bu isimlerin birçoğu; teknoloji, performans, müzik ve ses sanatını kendi çalışmalarında birleştirmişlerdir 
(Wands, 2006, s. 123). Beuys'un isminin Fluxus sanat hareketi içinde anılması Fluxus sanatçılarının ve Beuys'un sanatsal problematiğinin benzer paydada buluşması ile açıklamak mümkündür. Beuys'a göre de Fluxus için sanat, Duchamp öncesinde bize sunulan anlamda yücelik terimini içinde barındıran bir imayla sunulmaz. Sanat bir insan eylemidir. İnsan yaşam içinde var olur ve ondan her anlamda beslenir, dolayısıyla sanat da yaşamı yansıtmalı, hatta yaşamın kendisi sanat olmalıdır (Kılınç ve Reisoğlu, 2011, s. 223). Bu nedenle Fluxus sanatçıları ve Beuys, "hem gösterilerini içeriğini hem de gerekli becerileri, sanatçıları nesne üretiminden uzaklaştırarak, gerçek olaylara benzeyen ve gerçek zaman içinde yer alan süreç ve eylemlere yöneltmişlerdir" (Atakan, 1998, s. 66). Beuys'un Kavramsal yapıtları oldukça fazla olmasına rağmen genellikle bir Fluxus sanatçısı olarak tanımlanmıştır. Birleştirme yoluyla gerçekleştirdiği kuruluşları dağıtarak yeniden düzenlemeyle bir dizi Oluşum gerçekleştirmiştir. Bunlardan biri, 1965 yılında Wuppertal'da düzenlediği Eylem'dir. Bu Oluşumunda bir kutu üzerinde 24 saat süresince dimdik kolları iki yana açık vaziyette ayakta durmuş, kollarıyla devinebildiği uzay parçası içinde çevredeki nesneleri kullanarak çeşitli eylemler sergilemiştir (Kolektif, 1997, s. 232). Toplumsal heykel olarak adlandırdığı sanatının toplumu en iyi yönde şekillendirme gücünün olduğuna inanmıştır. Sanatçı, eğitim reformu, halkın demokrasisi ve Yeşiller Partisi kampanyalarına katılarak siyasete önem vermiş ve siyasette gittikçe daha aktif hale gelmiştir. Beuys, heykellerinde ve enstalasyonlarında kasıtlı olarak uçak kazasından kurtarılmanın da etkisiyle yağ, keçe, toprak, taş, yiyecek maddesi, bakır ve demir plakaları gibi malzemeler kullanmıştır. Oda büyüklügüündeki mekânlarda enstalasyonlar kurgulamıştır. 1982-87 yılları arasında eserleri ağaç dikme eylemi 7000 Meşe'de olduğu gibi müzelerden taşıp aktivist gösterilere dönüşmüştür. Beuys, sanatçının toplumla, sanat eserlerinin yanı sıra performans, halka açık tartışmalar ve siyasi kampanyalar gibi "eylemlerle" de iletişim kurabileceği fikrinin öncüsü olmuştur (Sanat Atlası, 2010, s. 558). Yapıtlarındaki bireyin tinsel ve düşünsel gelişimi ile ilgili iyimser boyut, sanatın iyileştirici, düzeltici bir araç olarak kullanılmasını önermesi, kutuplaşma ve yalıtılmışlığın üstesinden gelmek amacıyla önerdiği çözümler olmuştur. Sanatçı bu alt yapılar üzerine temellendirdiği sanatıyla, bir eylemci, bir kuramcı, bir oyuncu ve şaman olduğunu ortaya koymuştur (Şahiner, 2013, s. 59).

\section{Joseph Beuys Yapitları}

1960'l yıllar ve sonrasında Beuys'un sanatında sanat nesnesi ve mekân kurgusu farkı ıir bağlamda karşımıza çıkmaktadır. Sanatçı yaşamında büyük önem taşıyan yağ, keçe, toprak, taş, yiyecek maddesi, bakır ve demir plakaları gibi malzemeleri kurguladığı mekânlarla bütünleştirdiği yapıtlarında kullanmış ve yapıtlarında yaşamla bağ oluşturmuştur. Yapitlarında yer alan malzemeleri, mekân içerisine amacına uygun olarak belli bir düzen içinde yerleştirmiştir. Sanatçı mekânları kurgularken düzenlemeyi, izleyicinin hoşuna gitsin ya da güzel olsun diye yapmamış, çoğunlukla doğrudan kavramsal bir boyuta yönelmiştir. Sanatçı yapıtlarında ağırlıklı olarak galeride ki gerçek bir mekânı kurgulamış, izleyiciye günlük yaşamda ki bir mekânı sanatsal bir öğe olarak sunmuştur. Kurguladığı mekânlarla birlikte oluşturduğu düzeneklerin bir bütün olarak algılanmasını sağlamaya çalışmıştır.

Sanatçının sanatı, zihinsel bir durumun ya da özel bir eylemin biçimidir. Beuys'un kullandığı malzemeler ve yapıtlarını oluşturduğu düzenlemeler sanatın yeniden tanımlanmasına katkı sağlamıştır. Sanatçı için sanat dil, düşünce, performans, ölüm ve ekoloji konularıyla bağlantılı olmuştur (De Waresquiel, 2004, s. 104).

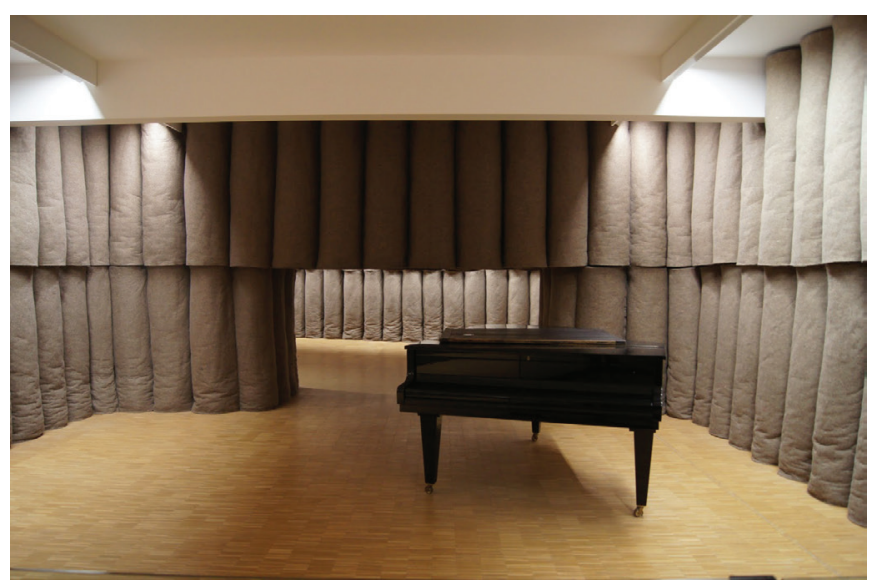

Resim 1. Beuys, “Kötü Durum”, 1958-1985, Anthony d’Offay Galerisi, Londra.

Beuys'un 1958-1985 yılında yaptığı Resim 1'deki "Kötü Durum” adlı yapıtı; büyük bir sanat galerisindeki iki odada; keçe, piyano, karatahta ve termometre ile meydana getirilmiştir. Yapıt, Londra Anthony d’Offay Galerisi'nde sergilenmiştir. Dikdörtgen biçimindeki galeride, iki ayrı mekânın duvarları, külrengi keçe ile rulo şeklinde yan yana 
dizilerek kaplanmıştır. Sanatçının kurguladığı mekânda keçe tomarları, duvarların yanlarına, iki sıra halinde odanın şekline uygun olarak sıralanmıştır. Beuys, üzerinde bir karatahtayla, bir termometre bulunan bir piyanoyu da galerinin tam ortasındaki boşluğa yerleştirmiştir. Mekânın tavanı beyaz renk bırakılmış, yerler ise parke kaplanmıştır. Sanatçının yapıtında ilgi odağı piyano olmuştur. Lynton (2004)'te sanatçının yapıtını şu şekilde yorumlamıştır:

Beuys'un düzenlediği (...) Keçe kaplı duvarlar mekâna belli bir ağırbaşlılık veriyor, ayrıca sıcaklık, korunmuşluk ve Londra'nın merkezindeki gürültüye karşı bir yalıtım kazandırıyordu. Kapalı piyano, boş karatahta ve kimin için ne ölçtüğü bilinmeyen termometre de insanların özlemleriyle yeteneklerini (...) dile getiriyordu (ss. 343-344).

Sanatçı yapıtının mekân düzenlemesinde kullandığı keçeleri önceki yapıtlarının tersine dikey olarak yerleştirerek, izleyiciye Kelt topraklarında bulduğu sıcaklık ve sağaltının sinyallerini vermek istemiştir. Termometreyi ise, Kelt topraklarında bulduğu sıcaklığı nicelleştirerek somutlaştırmak ve ısıyla ilgili kavramları destekleyeci bir eleman olarak sunmuştur. Sanatçı, Kelt toprakları ile anne karnının sıcak, güven veren yönü arasında ilişki kurmuş, fetüs durumuna geçmesiyle kendisini bu topraklarda yeniden yarattığına işaret etmiştir (Delibaş, 2008, s. 110).

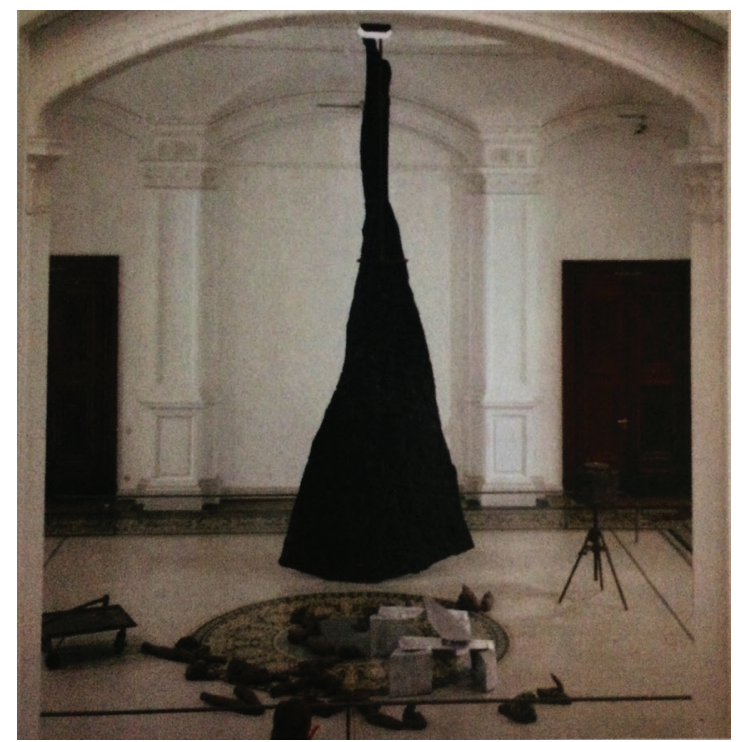

Resim 2. Beuys, "Şimşek ve Aydınlığında Geyik”, 1958-87, salon enstalasyonu, bronz, demir ve alüminyum, 1988, Zürih.
Sanatçı Resim 2'deki "Şimşek ve Aydınlığında Geyik” isimli yapıtını; bronz, demir ve alüminyum gibi malzemelerle düzenlediği farklı boyutlardaki nesnelerden oluşturmuştur. Mekân içerisinde kurgulanmış yapıtın oluşumunu sağlayan bu nesneler;solda üç tekerlekli bir el arabası, sağda, üzerinde fotoğraf makinasını andıran bir kutu bulunan tripot ve kutunun üzerinde bir pusula, ortada yerde, geyiği temsil etmesi amacıyla kullanılan alüminyum düzenek ve etrafına yerleştirilmiş farklı büyüklükteki şekiller, üst bölümden aşağıya sarkan yıldırım biçimiyle oluşturulmuştur.

Arketipik ve büyüsel-dinsel göndermeler Beuys'un düşüncesinde büyük rol oynamıştır. Şimşek Endüstri Çağı'nda sanatın işlevinin ne olduğunun üzerinde durmaktadır. Doğa ile ruh arasındaki karşılıklı diyalog biçimler ve malzemeler aracılığıyla simgelenmiştir (Buchholz vd., 2012, s. 499). Sanatçının yapıtında geyik Hıristiyan inancındaki gibi ruhun iletkeni olmuştur. Geyiğin boynuzlarının her yıl yenilenerek tekrar büyümesi yeniden diriliş ve ruhun arınmasının simgeleştirilmesidir. Ayrıca sanatçı erkek geyiği başlangıçta var olan hayvanların koruyucusu olarak kabul etmiştir (Kara, 2004, s. 70).

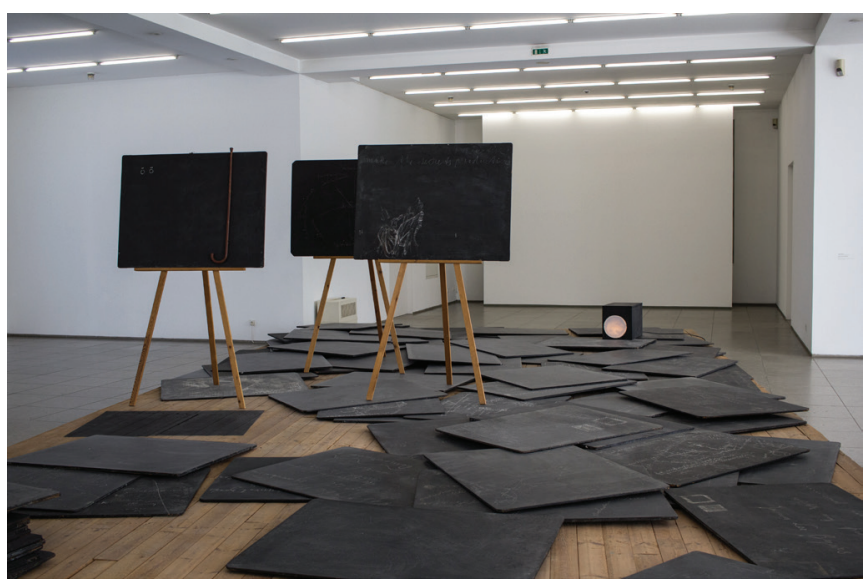

Resim 3. Beuys, "Yönlendirici Kuvvetler”, 1974.

Beuys, Resim 3'teki "Yönlendirici Kuvvetler" isimli çalışmasında toplam 100 adet karatahtayı mekânın zeminine yerleştirilen ahşap bir platform üzerine sermiş ve bunlardan üç tanesini şövaleye koymuştur. Bu şövalenin birinin üzerindeki karatahtaya sanatçı Gizlerin Üretimi yazmıştır. Karatahtalardaki diyagramlar ve çizimler yoluyla sanatçı, toplumunun köklü düşüncelerini sarsmak istemiş̧tir. Çalışmanın bir salın 
üzerinde gibi görünmesi, uzaktan yönlendirilen didaktik bir yaklaşımın, bilginin gizleriyle heykele dönüşmesidir (Şahiner, 2013, s. 63). Beuys çalışmalarında yazının anlatım aracı olma işlevinden yararlansa da onu bir yapıt olarak sunmuş olması yazıyı bir kavram olarak sunduğunu göstermektedir (Atakan, 1998 , s. 49). Karatahta ve yazı sanatçının çoğu çalışmasında görülmektedir. Sanatçının mekân içerisinde mekânın bir parçası haline getirdiği karatahtalar üzerindeki yazıları Şahiner (2013)' şu şekilde yorumlamıştır:

Şövalelerdeki üç karatahta, Beuys’un farklı bir entelektüel noktayı işaret ettiği 'eğitsel metinler'dir. Soldaki karatahtada yer alan 'ö-ö’, Dadaistler tarafından yaratılan fonetik şiirlere gönderme yapmaktadır (...). Beuys, bu yaklaşımıyla "duygusal tecrübelerimizi, düşüncelerimizle bütünleştirdiğimizde, sıradışı bir önermeye ulaşabiliriz" diyen Rudolf Steiner'e gönderme yapmaktadır (s. 63).

Sanatçı düşünceyi ve seslere bağlı olarak konuşmayı birer form olarak düşünen, içerisinde yer aldığımız dünyayı nasıl şekillendirdiğimizin bir tür heykel gibi algılanabileceğini iddia etmiştir. Beuys, sosyal heykel kavramını ileri sürerek, "bu bağlamda heykel, sosyal bir yapı olarak bir tür evrimsel süreçtir ve herkes de sanatçıdır." demiştir (Antmen, 2010, s. 207).

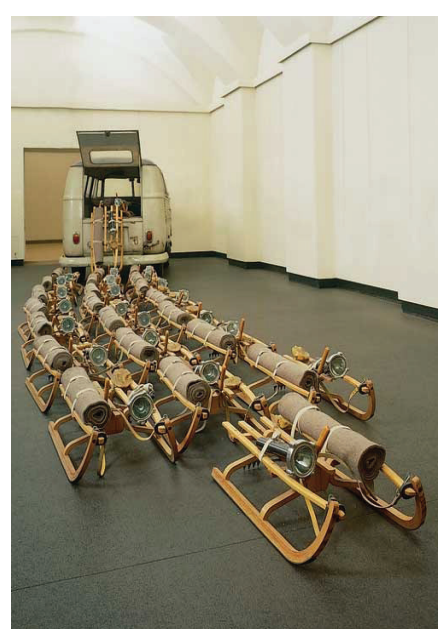

Resim 4. Beuys, "Sürü", 1969, Volkswagen minibüs ve her biri keçe, yağ ve el feneri taşıyan 24 adet kızak, Neue Galeri, Staatliche Müzesi, Kassell, Almanya.

Beuys Resim 4'teki Sürü isimli yapıtını Volkswagen minibüsün arkasından çıkan ve her biri keçe, yağ ve el feneri taşıyan 24 adet kızak ile birlikte mekân içerisine kurgulamıştır. Kızaklar minibüsün arkasına yerleştirilmiştir. Sanatçı bir aciliyet duygusuyla yapıtında hem işgali hem de hayatta kalma mücadelesi için kaçışı ima etmek istemiştir. Yapıtta her kızak; sıcaklık için sarılmış külrengi bir keçe, beslenme için yağ ve yolu bulmak için bir fener ile oluşturulmuştur (Fineberg, 2014, s. 222).

Beuys aksiyonlarından geriye kalan nesneleri, Sürü çalışması ve onun uzantısı olan kızaklarda olduğu gibi çoğaltmıştır. Sanatçının yapıtında nesneler tek tek ele alındığında bir anlam ifade etmezler. Sürü çalışmasında minibüsten çıkan kızaklar, M.Ö. 270’lerde Çin'de bulunan imparatorun ordusu gibidir. Ordunun birarada oluşu görsel etkiyi güçlendirmektedir. Benzer ilişki Sürü çalışmasında da görülmektedir. Beuys'un çoğaltmalarında taşıdığı güç, nesnelerin her bir çoğaltmada tekrardan yayılma olasılıklarını güçlendiren bir ağ gibi olmasından kaynaklanır. Sanatçının çalışmasında her uzantının bir kökten doğup gelişip, kendini de kök yaparak yaygınlaşmasıyla yatayına gelişen bir dizge oluşmaktadır (Biçer, 2007, s. 42).

Beuys'un yapıtına başka bir açıdan bakacak olursak, teknolojiyle üretilen Volkswagen minibüsü ile ilkel bir araç olan kızaklar çalışmasında bir araya gelmiştir. Bu çalışmayla bir iç mekânın kullanımı açısından yapıtın büyüklüğü, enstalasyonlarda yeni yaklaşımlara öncü olan bir örnek teşkil etmektedir. Beuys bu çalışmasını şu şekilde yorumlamıştır: (...) Aslında bu nüsha, VW. minibüsle yapılmış olandan daha büyük bir küme ile yapılmıştır. Fakat neden bu küme ebediyen bir arada kalsın ki? Dağılabilir de. Böylece dağılır. Bence bu türlü de bir arada durdukları zaman ki kadar iyi (Aktaran Biçer, 2007, s. 42; Schellman, Klüser, 1991, s. 14).

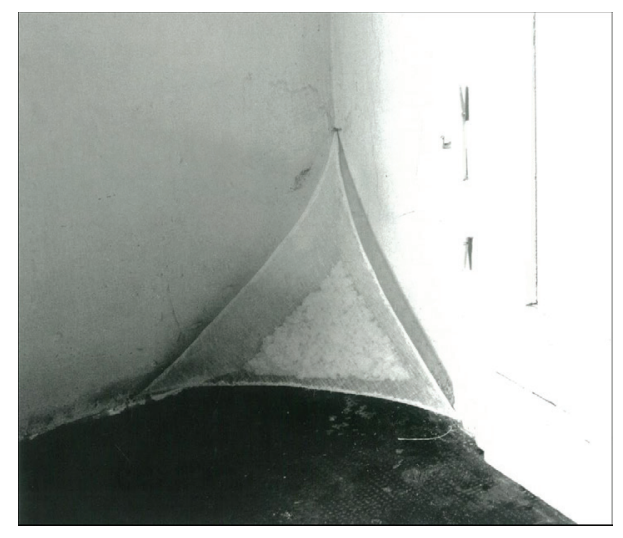

Resim 5. Beuys, “Yağ Köşesi”, 1963. 
Beuys'un bir diğer çalışması Resim 5’teki 1963 yılında yaptığı Yağ Köşesi isimli çalışması olmuştur. Sanatçı mekânın köşesine yerleştirdiği sıvı biçimli kaotik yağın, bir biçimlendirme etkinliği sonucunda, düzgün geometrik bir biçime kavuşmasını ifade etmiştir. Sanatçı için bu heykelciliğin temel prensibi haline gelmiştir. Heykelciliği daha geniş bir bağlamda ele alan sanatçı için; istenç, duygu ve düşünme kavramları da benzer bir etkileşim içinde olmuştur. İstenç kaotik olana, duygu harekete ve düşünme kavramı da biçime karşılık gelmiştir (Kuoni, 1993, s. 91).

Beuys Yağ Köşesi isimli yapıtında olduğu gibi diğer yapıtlarında da malzeme olarak kullandığı yağı kullanma amacını şu şekilde belirtmiştir:

Yağ kullanmaya, tartışma yaratma niyetiyle başladım (...). İstediğim şey, kültür ve heykelin ne anlattığı, dil denen neyin ne olduğu, insan yaratıcılığı ve üreticiliğinin ne anlama geldiği gibi konuları, yani kısaca, kültür ve heykelin gizilgücünü tartışmaya açmaktı (Yılmaz, 2006, s. 276).

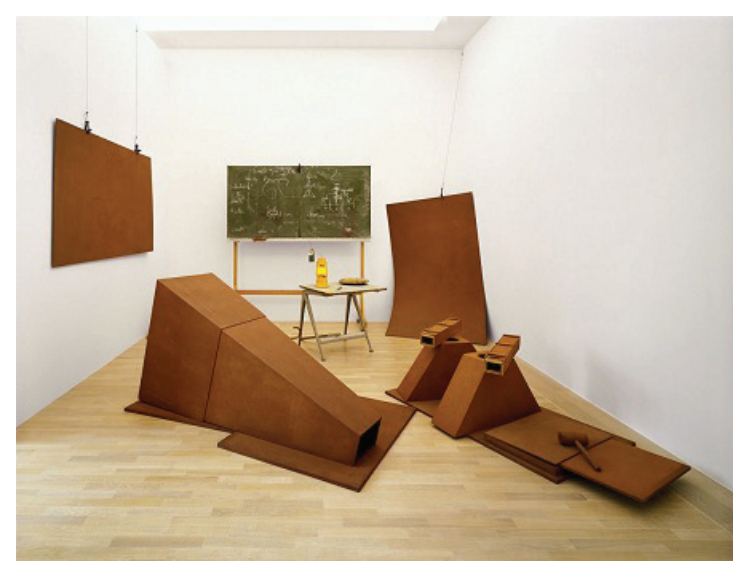

Resim 6. Beuys, “Kamptan Ayrılmadan Önce Ben”, 1970/80, Münih.

Sanatçının Resim 6'daki Kamptan Ayrılmadan Önce Ben isimli çalışmasında sol tarafta duvara asılı bir ilan panosu bir de köşeye kıvrılmış bir şekilde yerleştirilmiş bir pano görülmektedir. Mekânın orta bölümünde büyük pramidal bir şekil, pramidal kutular, mekânın zeminine yerleştirilmiş plakalar ve kamalar kullanılmıştır. Mekânın karşı duvarına dayalı okul yazı tahtasını bir kez daha kurulumun merkezi olan bir unsur olarak kullanılmıştır. Yazı tahtasının üzerine fikirlerini tebeşir ile çizmiştir. Yazı tahtasının önündeki küçük sehpa üzerinde bir lamba ve bıçak yer almakta, bıçağın ucu pusula gibi yön göstermektedir. Yerde ahşap plakaların üzerinde bir ahşap çekiç yer almaktadır.

Sanatçı günlük yaşamdaki klasik geometrik formları mekânla kurgulayarak yapıtına dönüştürmüştür. Sanatçının çalışmasına hâkim derin kırmızımsı kahverengi tonu çalışmadaki nesnelerde görülmektedir. Sanatçı bir kamptan hareket ederek yapıtını kampa uygun olarak düzenlenmiş nesnelerle oluşturmuştur. Beuys mekân kurgusu içerisinde çalışmalarında kullandığı nesnelerle ilgili şu şekilde yorum yapmıştır:

Benim nesnelerim, heykel düşüncesinin ya da genel olarak sanatın dönüştürülmesi için birer uyarıcı olarak görülmelidir. Onlar heykelin ne olabileceğini ve heykel yapma kavramının nasıl herkesin kullandığı görülmez malzemeler kadar yaygınlaştırılabileceği konusunda düşünceleri tahrik etmelidirler (Pektaş, 2006, s. 44).

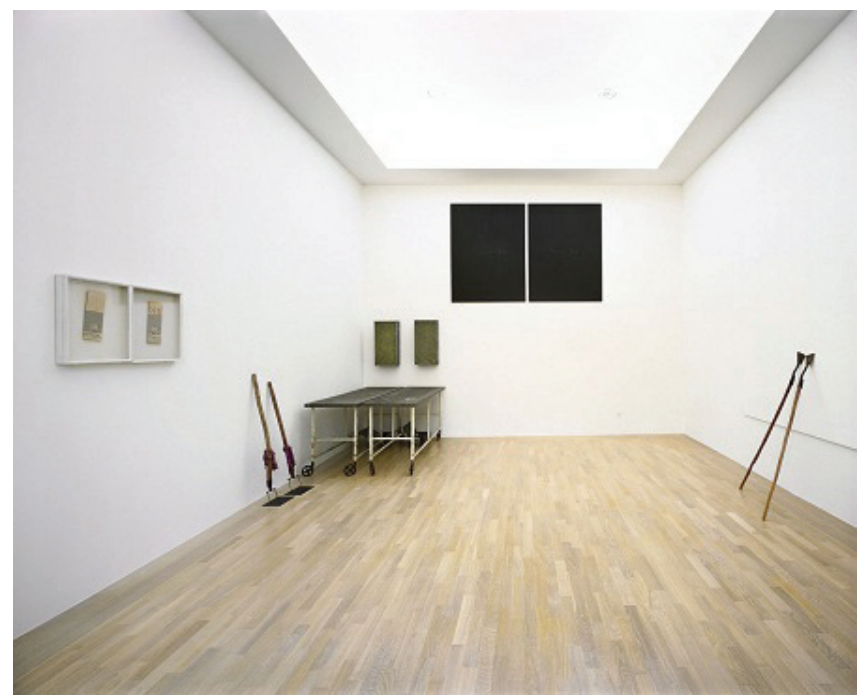

Resim 7. Beuys, “Yaranı Göster”, 1974-75, Münih.

Sanatçı Resim 7'deki Yaranı Göster isimli çalışmasını iki siyah tahta, gazete, iki tarım aleti, iki çift demiryolu parçalarını bastırıp sıkıştırmak için kullanılan çatal uçlu alet, iki morg masası, morg masasının altında yağ ile doldurulmuş iki metal kutu, termometre, kavanoz, gazlı bez ve test tüpü ile 
oluşturmuştur. Bu malzemeler sanatçı için bu işin bir parçası haline gelen malzemelerdir. Beuys'a hitap eden gazetenin iki kopyası, tebeşir ile yazılabilir iki okul karatahtası mekânın duvarında yan yana asılmıştır. Beuys, heykeltıraşlık eserlerinin çoğunda olduğu gibi malzemeleri çift olarak sunmuş, bu şekilde toplumun yaşam ve ölüm ikiliği yansıtmak istemiştir.

Beuys, Yaranı Göster isimli çalışmasında şamanik terapi unsurunu ele almıştır. Sanatçı mekânı içerisine bir hastane odasının malzemelerini dâhil ederek kurgulamıştır. Çalışma Beuys ve Almanya için psikoterapik bir işleve sahiptir (Merdaner, 2010, s. 82). Sanatçı; hastalık, acı, ölüm, travma, yaşlılık ve geçicilik konularını vurgulamak istemiştir. Burada verdiği mesaj ise gösterilen bir yaranın tedavi edilebilir olduğudur.

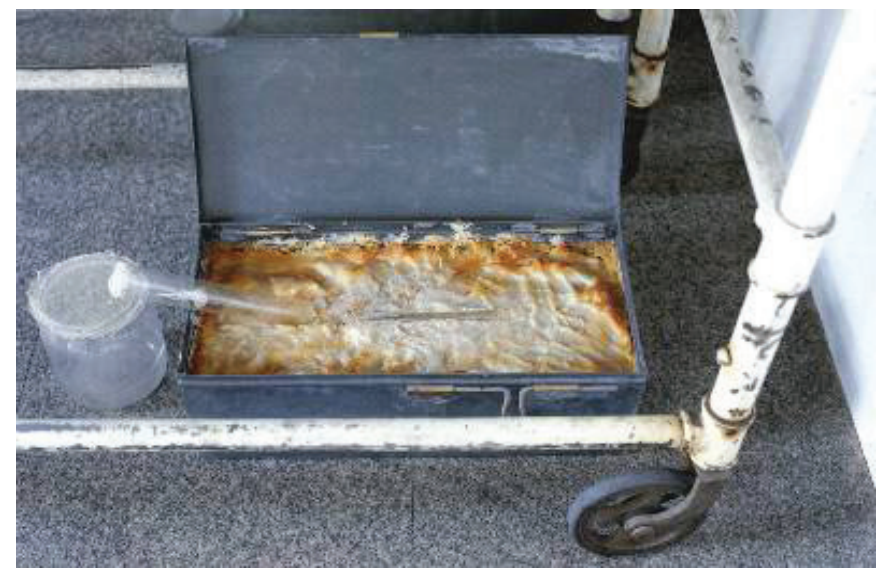

Resim 8. Beuys, “Yaranı Göster” (ayrıntı), 1974-75, Münih.

Resim 8'de görüldüğü gibi sanatçı çalışmasında morg masasının altına yağ ile doldurulmuş iki metal kutu yerleştirmiştir. Metal kutunun hemen yanında gazlı bez ile kaplı kavanoz, kavanozun üzerinden test tüpü kutunun içine doğru konumlandırılmıştır. Kutudaki yağın üzerinde de termometre görülmektedir. Kutular aynı bu şekilde birbirine paralel olarak masaların altına yerleştirilmiştir.

\section{Sonuç}

Joseph Beuys, 1960’lı yılların öncü sanatçılarından biri olmuştur. Sanatçı bu yıllarda, resim, heykel, performans ve enstalasyonlar yapmıştır. Sanatçının geçmişte yaşadığı uçak kazası sanatçının yaşamı, yapıtları, kullandığı malzemeler ve düşüncelerinde önemli değişiklikler yaratmıştır. Resimden performans sanatına geçiş yapmasında, sanatın toplumda daha çok etkili olması gerektiğine olan inancı ile hareket etmiştir.

Sanatçının yapıtlarının bir iç mekânın kullanımı açısından kapladığı alan, enstalasyonlarda yeni yaklaşımlara öncü olan bir örnek teşkil etmesi açısından önem taşımaktadır. Sanatçı yapıtlarını oluştururken mekânı da kurgulayarak yapıtına dâhil etmeyi amaçlamıştır. Kurgulanan gerçek mekân nesnelerin yerleştirilmeleriyle izleyiciye farklı yaşanmışlıklar sunmaktadır. Sanatçının kurguladığı mekânlar sanatçının yapıtlarıyla anlam kazanmıştır. Sanatçının yapıtları galeri ya da yapıtlarını oluşturduğu gerçek mekâna uygun şekilde mekânla birlikte kurgulandığı için mekâna özgü olan yapıtlar olarakta görülmektedir. Sanatçı bazı yapıtlarında mekânın tamamını kurgulamış ve mekânı bağlamından uzaklaştırarak yapıtıyla birlikte oluşturmuştur. Bu şekilde mekânlar içerisine düzenlediği yapıtla birlikte mekânı da yapıta özel kurgulayarak dâhil etmiştir. Sanatçı içinde bulunduğumuz mekânları, yapıtıyla doğrudan bir ilişki içerisinde duyularımıza etki edecek şekilde düzenlemiştir. Ayrıca sanatçı yapıtlarında onun için önem taşıyan birçok malzemeyi sembol olarak kullanarak yapıtlarıyla mesajlar vermek istemiştir.

\section{Kaynaklar}

Antmen, A. (2000). A'dan Z’ye 20. yüzyıl sözlügüu. P Sanat Kültür Antika Dergisi, Kış 2000 (16), 17-30.

Antmen, A. (2010). Sanatçılardan yazılar ve açıklamalarla 20. yüzyıl batı sanatında akımlar. İstanbul: Sel Yayıncılık.

Atakan, N. (1998). Arayışlar resimde ve heykelde alternatif akımlar. İstanbul: Yapı Kredi Yayınları.

Beykan, M. (Ed.) (1997). Sanat kitabı: 500 sanatçı 500 sanat eseri (Çev. Mina Haydaroğlu). İstanbul: Yem Yayın.

Biçer, Y. (2007). Plastik bir olgu olarak çoğaltma. Artist Modern Dergisi, Aralık 2007, 11(84), Artist Yayın

Endüstrisi ve Eğitim Hizmetleri Ltd., İstanbul, 36-43.

Buchholz, E., L., Bühler, G., Hille, K., Kaeppele, S., Stotland, I. (2012). Sanat (Başvuru Kitapları). İstanbul: NTV Yayınları.

Coşkun Onan, B. (2017). Postmodern Sanatta Nesne ve Mekân Bağlamı: İki Türk Kadın Sanatçı, Atatürk Üniversitesi Güzel Sanatlar Enstitüsü Dergisi, Sayı / Number 38, Erzurum, 2017, 37-50

De Waresquiel, E. (2004). İsyankâr yüzyıl, Yirminci yüzyılın başkaldırı sözlüğü (Çev. İ. Yerguz). İstanbul: Sel Yayıncılık. 
Delibaş, L. (2008). Kelt kültürü bağlamında Joseph Beuys ve eserleri. (Yayımlanmamış Yüksek Lisans Tezi). Marmara Üniversitesi, İstanbul.

Fineberg, J. (2014). 1940’tan günümüze sanat. İzmir: Karakalem Kitabevi Yayınları.

Genç, A. (2007). Köktenci sanatta devrimsel gelgit: kavramimge diyalektiği. Beykent Üniversitesi Sosyal Bilimler Dergisi (1), 153- 175.

Kara, D. (2004). Bir biyofilik olarak Joseph Beuys ve sanatı. (Yayımlanmamış Yüksek Lisans Tezi). Marmara

Üniversitesi, İstanbul.

Kılınç, G., M., Reisoğlu, O., O. (2011). Joseph Beuys ve Bir Evrim Katalizörü Olarak Sanat. 1. Sanat ve Tasarım Eğitimi Sempozyumu, Dün Bugün Gelecek Bildiri Kitabr. Denizbank.

Kolektif (1997). Eczacıbaşı sanat ansiklopedisi (Cilt 1.) Tükel, U. Joseph Beuys (s. 232). İstanbul: Yapı- Endüstri Merkezi Yayınları.

Kuoni, C. (1993). Joseph Beuys in America, energy plan for the western man, writings by and interviews with the artist. Four Walls Eight Windows, New York.

Lynton, N. (2004). Modern sanatın öyküsü (Çev. C. Çapan). İstanbul: Remzi Kitabevi.

Merdaner, E. (2010). Şamanizm bağlamında Joseph Beuys'un sanatı. (Yayımlanmamış Yüksek Lisans Tezi). İstanbul Teknik Üniversitesi, İstanbul.

Paust, B. (2005). Aslolan çizgidir: Joseph Beuys'un eserlerinde çizimin önemi, Joseph Beuys - aslolan çizgidir, Schloss Moyland Müzesi Koleksiyonundan Bir Seçki, İstanbul: Yapı Kredi Yayınları.

Pektaş, N. (2006). Kaidesiz heykel. Artist Dergisi, Haziran 2006, Artist Yayın Endüstrisi ve Eğitim Hizmetleri Ltd., İstanbul, 40-46.

Sanat Atlası (2010). Sanat atlası dünyanın en kapsamlı müze kitabı. Seçkin Selvi (Ed.). İstanbul: Boyut Yayıncılık.

Schellman, J., Klüser, B. (1991). Joseph Beuys' a sorular (Çev. Sebla Kiraz), Hürriyet Gösteri Sanat Edebiyat Dergisi (Joseph Beuys Özel Sayı), Sayı: 133, İstanbul.

Schmuckli, C. (2004). Chronology and selected exhibition history. In Rosenthal, M., with Rainbird, S. and Schmuckli, C. Joseph Beuys actions, vitrines, environment (pp. 150-201). London: Tate Publishing.

Şahiner, R. (2013). Sanatta postmodern kırılmalar. Ankara: Ütopya Yayınevi.
Şen, Ö. (2006). Yirminci yüzyılda avangard sanatın etkisinde dönüşüme uğrayan desen anlayışının Joseph Beuys örneğinde incelenmesi. (Yayınlanmamış Yüksek Lisans Tezi). Çukurova Üniversitesi, Adana.

Yılmaz, M. (2006). Modernizmden postmodernizme sanat. Ankara: Ütopya Yayınevi.

Wands, B. (2006). Dijital Çağın Sanatı. İstanbul: Akbank Kültür ve Sanat.

\section{Resimler Listesi}

Resim 9: Joseph Beuys, “Kötü Durum”, 1958-1985, Anthony d’Offay Galerisi, Londra (http://natti-noo-noo.blogspot. com.tr/2012/01/joseph-beuys.html). Erişim Tarihi: 08.10.2016.

Resim 10: Beuys, “Şimşek ve Aydınlığında Geyik”, 1958-87, salon enstalasyonu, bronz, demir ve alüminyum, Berlin Sergisi'nden fotoğraf 1988, Zürih (Buchholz, E., L., Bühler, G. vd., 2012, 499).

Resim 11: Beuys, “Yönlendirici Kuvvetler”, 1974 (http:// flickrhivemind.net/blackmagic. cgi?id=25478987246\&url). Erişim Tarihi: 18.10.2016.

Resim 12: Beuys, “Sürü”, 1969, Volkswagen minibüs ve her biri keçe, yağ ve el feneri taşıyan 24 adet kızak, Neue Galeri, Staatliche Müzesi, Kassell, Almanya (Fineberg, 2014, s. 222).

Resim 13: Beuys, "Yağ Köşesi”, 1963 (http://julianminima. tumblr.com/post/8196498952/joseph-beuys-filter-fatcorner-1963). Erişim Tarihi: 12.10.2016.

Resim 14: Beuys, “Kamptan Ayrılmadan Önce Ben”, 1970/80, Münih. (Foto: Florian Holzherr) (http://www. lenbachhaus.de/exhibitions/sammlungspraesentation/j oseph-beuys/?L=1). Erişim Tarihi: 05.10.2016.

Resim 15: Beuys, “Yaranı Göster”, 1974-75, Münih (Schmuckli, 2004).

Resim 16: Beuys, "Yaranı Göster" (ayrıntı), 1974-75, Münih (Schmuckli, 2004). 